\title{
Environmental Effects of Historical Mining in the Animas River Watershed, Southwestern Colorado
}

\section{The U.S. Geological Survey has completed an extensive environmental study of the effects of historical mining on water and sediment quality and aquatic and riparian habitat in the Animas River watershed upstream from Silverton, Colorado. Results from this study are being used by Federal and State agencies and by the local watershed stakeholders group to implement remediation and cleanup activities.}

The Watershed Approach provides an effective means to rank and evaluate environmental impact of historical mining throughout a region: The mining-related sites that, upon evaluation, are shown to cause the greatest impact can become the subjects of remediation planning and implementation. This process helps land managers evaluate risk and focus remediation efforts on sites that may be the most deleterious to water quality and aquatic and riparian habitat.

The Animas River watershed is one of many watersheds in the western United States where historical mining has left a legacy of acid mine drainage that results in elevated concentrations of potentially toxic trace elements. Many inactive mine sites are located on or directly affect Federal lands. Cleaning up these Federal lands and restoring the watersheds will require a substantial investment of resources and many years of work before the aquatic ecosystem can recover. As part of a cooperative effort with Federal land-management agencies, State natural resource agencies, the U.S. Environmental Protection Agency, and concerned local citizens, the U.S. Geological Survey (USGS) implemented the Abandoned Mine Lands Initiative in 1997. USGS scientists have since completed a comprehensive study to understand processes and assess sites in the watershed for remediation. These data, coupled with those collected from private sites by the Animas River Stakeholders Group, State of Colorado, Bureau of Land Management, and USDA Forest Service, will be used by regulatory agencies having the responsibility for watershed cleanup.

Results of this investigation, published in USGS Professional Paper 1651, include studies of geology, rock and sediment geochemistry, surface- and groundwater geochemistry, a mine inventory, district production and milling history, and distribution and health of aquatic risk assessment for trout summarizes the biological impact of historical mining on aquatic fishery resources. Viable trout populations are present in some tributaries and parts of the Animas River upstream from the confluence with Mineral Creek, suggesting some overall improvement of aquatic habitat quality. However, little to no aquatic life occurs in the upper Animas River upstream of Animas Forks, the entire length of Cement and Mineral Creeks, and several smaller tributaries. Historically, parts of Cement and Mineral Creeks, the two major tributaries in the study area, were always acidic, contained high metal loads, and likely did not support any aquatic life other than species of algae that can tolerate those acidic conditions $(\mathrm{pH}<4)$. Finally, the Professional Paper outlines the potential for long-term monitoring as a means to document

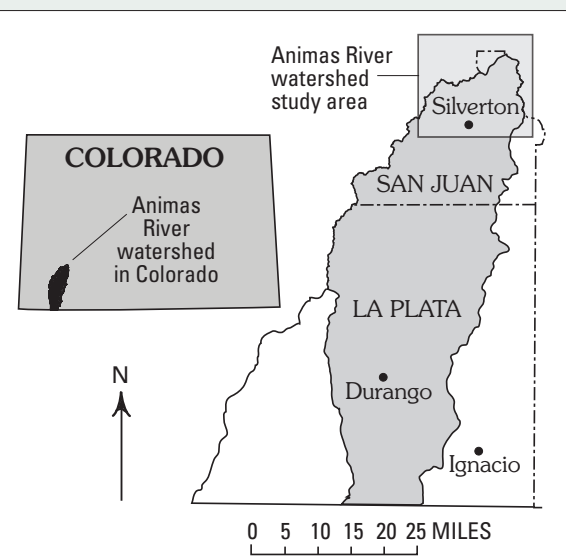

and riparian biota. An environmental

ecological recovery following remediation implemented in the past decade by Sunnyside Gold, Inc., the Federal and State land-management agencies, and the Animas River Stakeholders Group. A compact disc of data collected during the study accompanies the volume.

\section{Setting and Geology}

The Animas River watershed study area (fig. 1), approximately 145 square miles, covers the northern portion of the Animas River drainage basin upstream of Silverton, Colo.; it also includes an extension south to Elk Park. Upstream from Silverton, the drainage basins of the three main tributaries, Mineral Creek, Cement Creek, and Animas River, delineate a rugged montane basin, ranging in elevation from 9,305 ft at Silverton to more than $13,800 \mathrm{ft}$ in the surrounding mountains. Elevations of the three Red Mountains (banner photo at top) range from 12,219 to $12,747 \mathrm{ft}$; these three peaks form the northwest boundary of the study area. The study area is accessible by U.S. Highway 550, from Durango on the south or from Ouray on the north.

The study area is underlain by Precambrian and Paleozoic rocks that were intruded and overlaid by the Oligocene Silverton Volcanics in a major caldera-forming event. Ring fractures control the course of the Animas River and Mineral Creek upstream from Silverton. Mineralization in the watershed was extensive, comprising at least five different periods beginning in the Oligocene, 30 million years ago, and ending about 5 million years ago. Hydrothermal alteration has resulted in widespread areas of disseminated pyrite throughout the study area, weathering of which has resulted in large barren, iron-stained areas (banner photo) that release large amounts of acid and metals to surface and ground water.

Figure 1. General location map of study area, southwestern Colorado, U.S.A. 


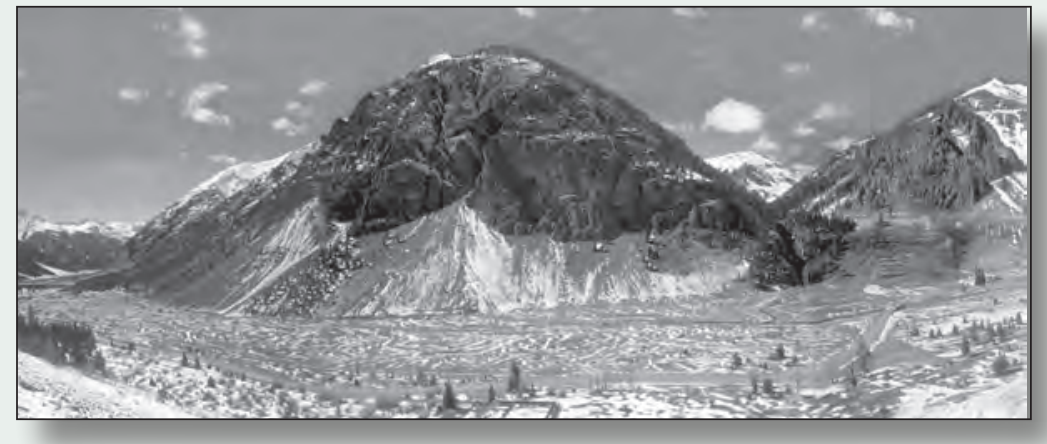

Figure 2. Animas River valley at Eureka. Foundation of Sunnyside Eureka Mill is on hill at far left above road. Riparian zone downstream from the mill site was completely obliterated by discharge and storage of mill tailings during the mill's operation (1917-1930). About 1 meter of sediment accumulated on the flood plain as a result of disposal of mill tailings in the Animas River. The site was remediated by Sunnyside Gold, Inc., in 1996. Photograph by Kirk Vincent (1999).

\section{The Mining Era}

Sometime during the 1700 s, Spanish explorers discovered placer gold in Arrastra Creek, a tributary of the upper Animas River. Serious mineral exploration began in the early 1870 s following discovery of placer gold by the Baker reconnaissance scouting team for the U.S. Army. Mining began in 1872 following a treaty with the Ute Tribe and continued through 1991-when the last remaining site, the Sunnyside mine, closed. Mineral deposits include copper- and silver-rich breccia-pipe deposits associated with subeconomic porphyry copper-molybdenum deposits, and base- and precious-metal vein deposits containing silver, lead, zinc, and gold in hydrothermal vein deposits. The most productive mineral deposits were vein deposits mined primarily for their silver content.

Silver, lead, and gold were the primary commodities. Zinc was produced in minor quantities prior to World War I, but it became a major commodity following the introduction of pre-flotation processing in 1915. Zinc production expanded after the Sunnyside Eureka flotation mill opened in 1917, until the Great Depression forced the mine and mill to close. Much of the total mineral wealth extracted from the gold-bearing vein deposits came from the Shenandoah-Dives and Sunnyside mines in the upper Animas River basin. Total mineral production from the area is estimated at 18.1 million short tons of ore.

Mining and milling processes in the Animas River watershed are typical of those practiced throughout the West during the 19th and 20th centuries. Beginning in 1872, vein deposits were mined underground by small crews who selectively mined high-grade ore. Ore was hand-sorted and sent to smelters by mule pack train and later by wagon. Waste rock was discarded in open mine stopes or on mine-waste dumps outside the portal where the hand sorting was done. As more efficient methods of mining and milling were developed and rail transport became available, increasingly larger amounts of lower grade ore were mined and processed. Waste rock was disposed of on mine-waste dumps outside the mine portal, and mill wastes were deposited into the nearest stream course. By 1930, before it closed due to falling metal prices during the Depression, the Sunnyside Eureka Mill (fig. 2) was processing more than 1,000 short tons of ore per day. Mill wastes were disposed of on the riparian zone of the Animas River and were periodically washed downstream by high spring runoff. Beginning about 1935, mill wastes from the Shenandoah-Dives mine were retained in tailings ponds at the Mayflower Mill site. An estimated 8.6 million short tons of mill waste, about 47.5 percent of the total ore produced, were discharged into surface streams between 1872 and about 1935 .

\section{Environmental Effects}

Historical mining occurred during a time when environmental effects of mining were poorly understood and of little understanding or concern to much of society. Effects of mining are noticeable throughout the watershed (fig. 3). In many stream reaches, elevated traceelement concentrations are the direct result of historical mining exemplified by zinc (fig. 4). Other potentially toxic trace elements ( $\mathrm{Al}, \mathrm{Cd}, \mathrm{Cu}, \mathrm{Pb}$, and $\mathrm{Mn}$ ) in both water and sediment resulting from historical mining activity show the same general distribution patterns. The presence of Paleozoic carbonate rocks as well as the carbonate in propylitic hydrothermal alteration in the upper Animas River basin resulted in good near-neutral water in the Animas River and many of its west-flowing tributaries (fig. 5). Tracer studies conducted in the watershed indicate that the Animas River upstream from Cement Creek contributes the largest portion of the manganese. In contrast, water from Mineral Creek contributes

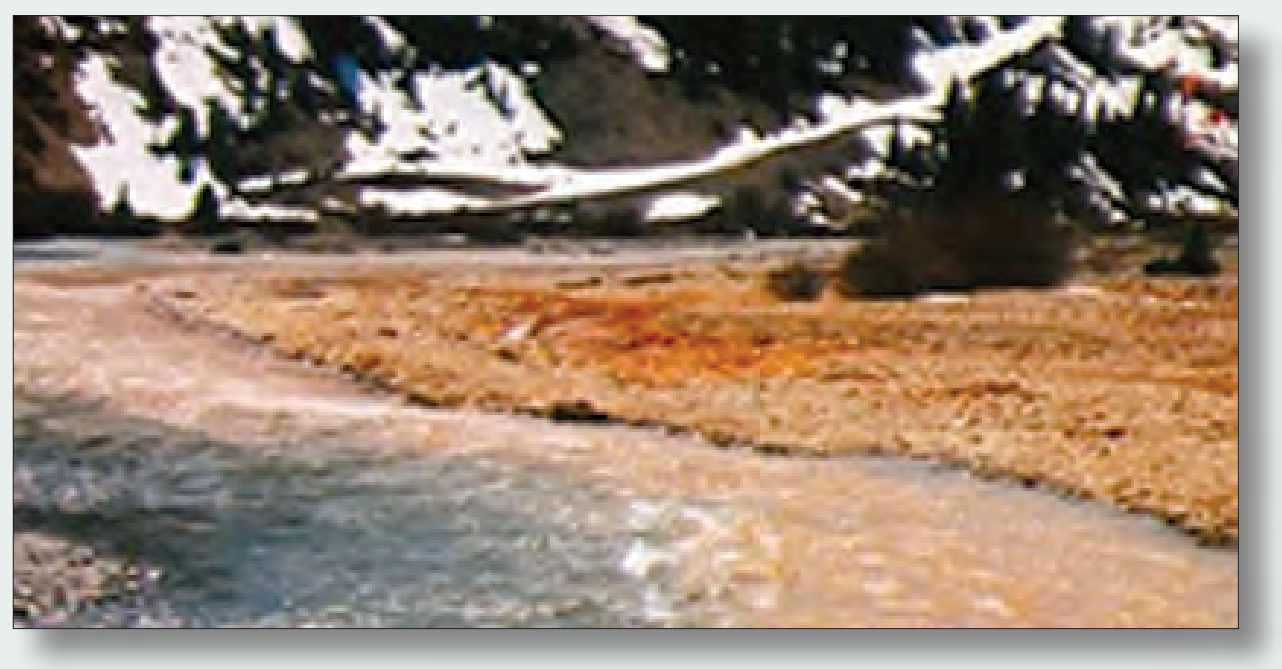

Figure 3. View looking downstream (southwest) from confluence of Cement Creek (right) with Animas River (left). Iron colloids precipitate from more acidic surface water in Cement Creek ( $p H \approx 3.5$ ) upon mixing with more neutral water of Animas River. Some of the iron and much of the toxic metal load in Cement Creek are the result of historical mining in the Cement Creek basin. 


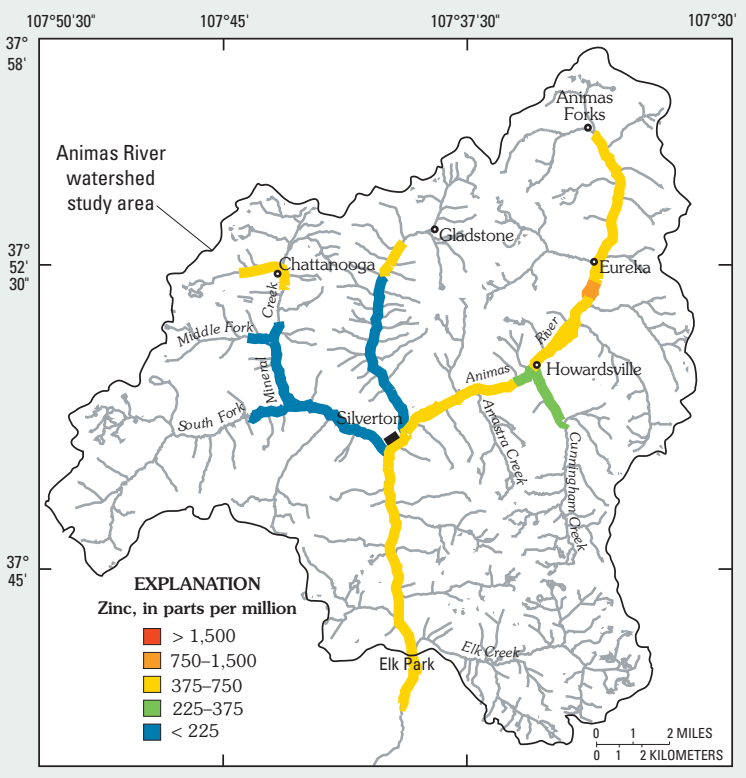

A

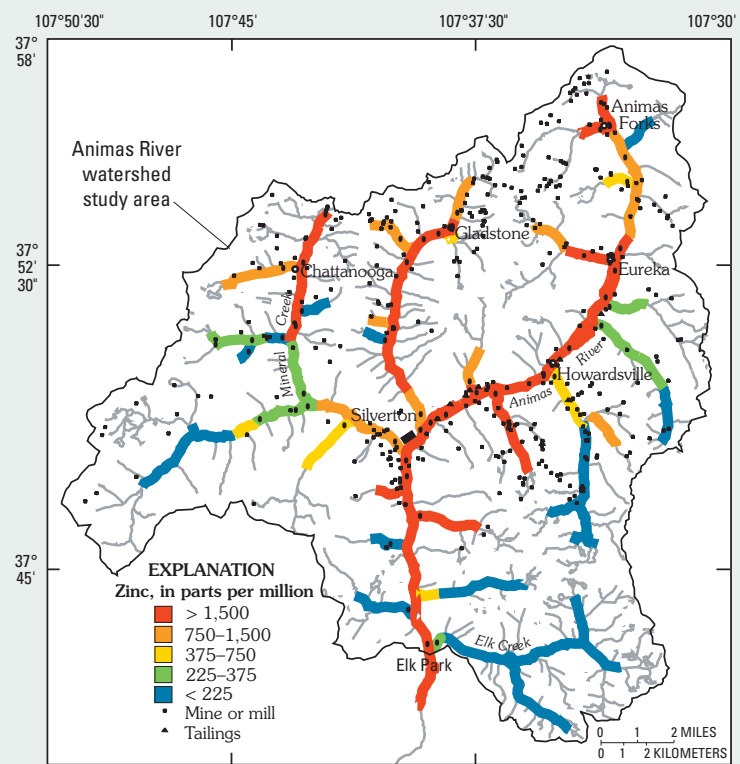

B

Figure 4. Zinc concentrations in $A$, pre-mining sediment, and $B$, modern sediment.

the largest portion of the copper load and Cement Creek the largest portion of the zinc and aluminum loads (fig. 6).

Not all of the poor water quality, degraded habitat, and acidic streams resulted from mining activities (fig. 4). Water chemistry and the colorful landscape in the western part of the watershed resulted from the weathering of altered pyritic rock (banner photograph). Weathering of pyrite in hydrothermally altered areas of the watershed prior to mining also results in significantly degraded water quality. The presence of numerous ferricrete deposits in both Cement and Mineral Creeks directly associated with extensive hydrothermal alteration in the western part of the study area is indicative of this process. For example, dissolved zinc concentrations measured in surface water vary widely throughout the watershed (fig. 5) and are also directly correlated with areas of extensive hydrothermal alteration. Releases of cadmium and copper from weathering of hydrothermally altered rock also limited viable aquatic habitat prior to mining.

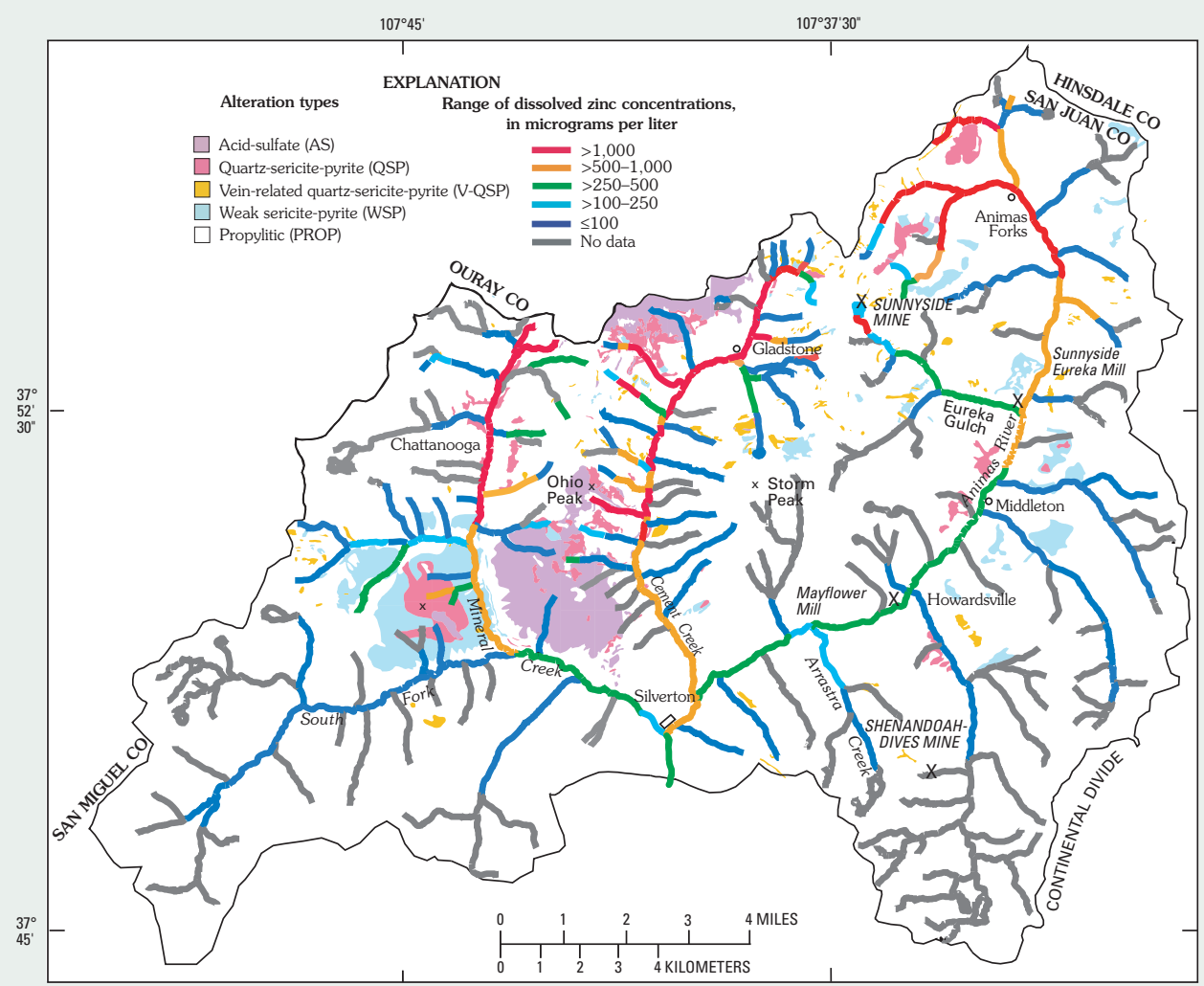

Ecological impairment and habitat degradation are reflected through reduced abundance and diversity of aquatic invertebrates, and in some cases, the absence of a viable fish community. Native cutthroat trout have been largely eliminated from study area streams with the exception of a few tributaries, and brook trout are now the only widespread fish species. Suitable winter habitat for trout is limited by the availability of deep pools; many of these have been filled or shallowed by the large sediment loads dumped into the surface drainage by historical mills. Biological data collected during this study allowed the assessment of current stream health and established a pre-remediation baseline for benthic macroinvertebrate populations and trout. Combining these data with hydrothermal alteration mapping, streamsediment geochemical data, and groundand surface-water quality data provided a basis for a risk assessment for trout in the Animas River watershed (fig. 7). The distribution of fish and benthic macroinvertebrates in the watershed generally reflected estimated toxicity risks associated with concentrations of aluminum, cadmium, copper, and zinc, which occurred at potentially toxic concentrations in acidic stream reaches, although risks varied widely in neutral waters. Toxicity risk was greatest during late winter at base flow, especially in stream reaches where seasonal acidification took place.

Figure 5. Distribution of dissolved zinc in surface water at low flow (late fall). 

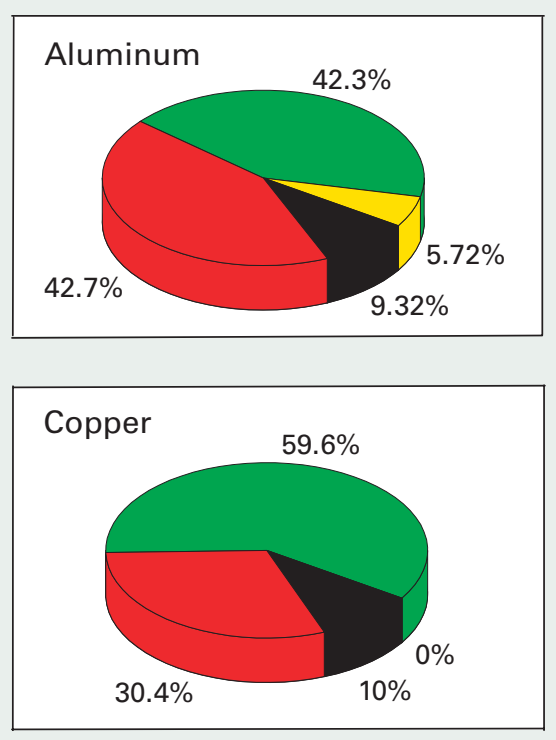

Animas River Cement Creek
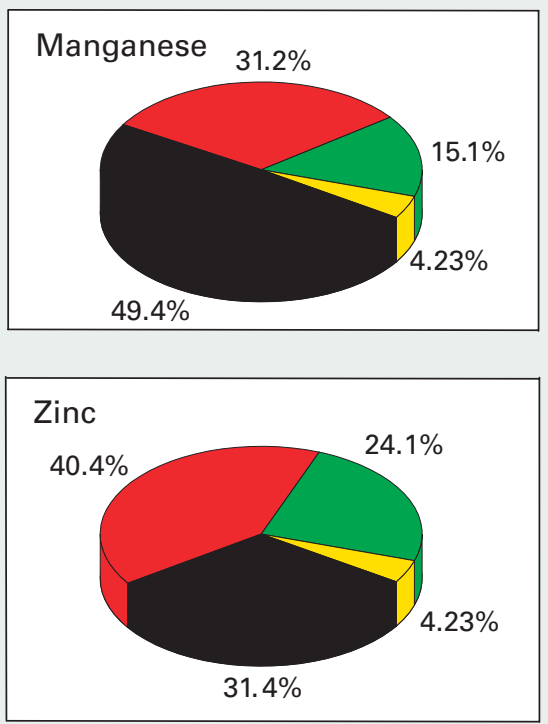

Mineral Creek
Figure 6. Percent of the total dissolved load of $\mathrm{Al}, \mathrm{Mn}, \mathrm{Cu}$, and $\mathrm{Zn}$ calculated from tracer data, Animas River, Cement Creek, Mineral Creek, and Elk Creek.

Monitoring is an important tool for documenting the effectiveness of any remediation effort and assessing the recovery of ecological systems. With properly collected monitoring data, land managers can be more objective about the success of projects undertaken and remediation goals met, and they can learn from application of new remediation and reclamation technologies. Monitoring data are currently being collected by the Animas River Stakeholders Group and the Federal land-management agencies.

\section{Mine-Site Remediation and Monitoring}

As of 2004, funding for 20 remediation projects was provided by Echo Bay, the parent company of Sunnyside Gold, Inc., prior to their release from their surface-water discharge permits. Many former mine sites operated by Sunnyside Gold, Inc., and its predecessors were cleaned up; draining mine adits were plugged; and mill tailings and mine wastes were moved to the Mayflower repository. Applying the watershed approach, Federal land-management agencies have remediated nine sites that contributed large metal loads to surface waters. The Animas River Stakeholders Group has secured funding, largely in the form of NPS 319 grants from EPA, to conduct remediation work on nine sites on private land. Remediation work is ongoing and will continue for many years.

Figure 7. Zinc toxicity map showing categories of risk to aquatic life.

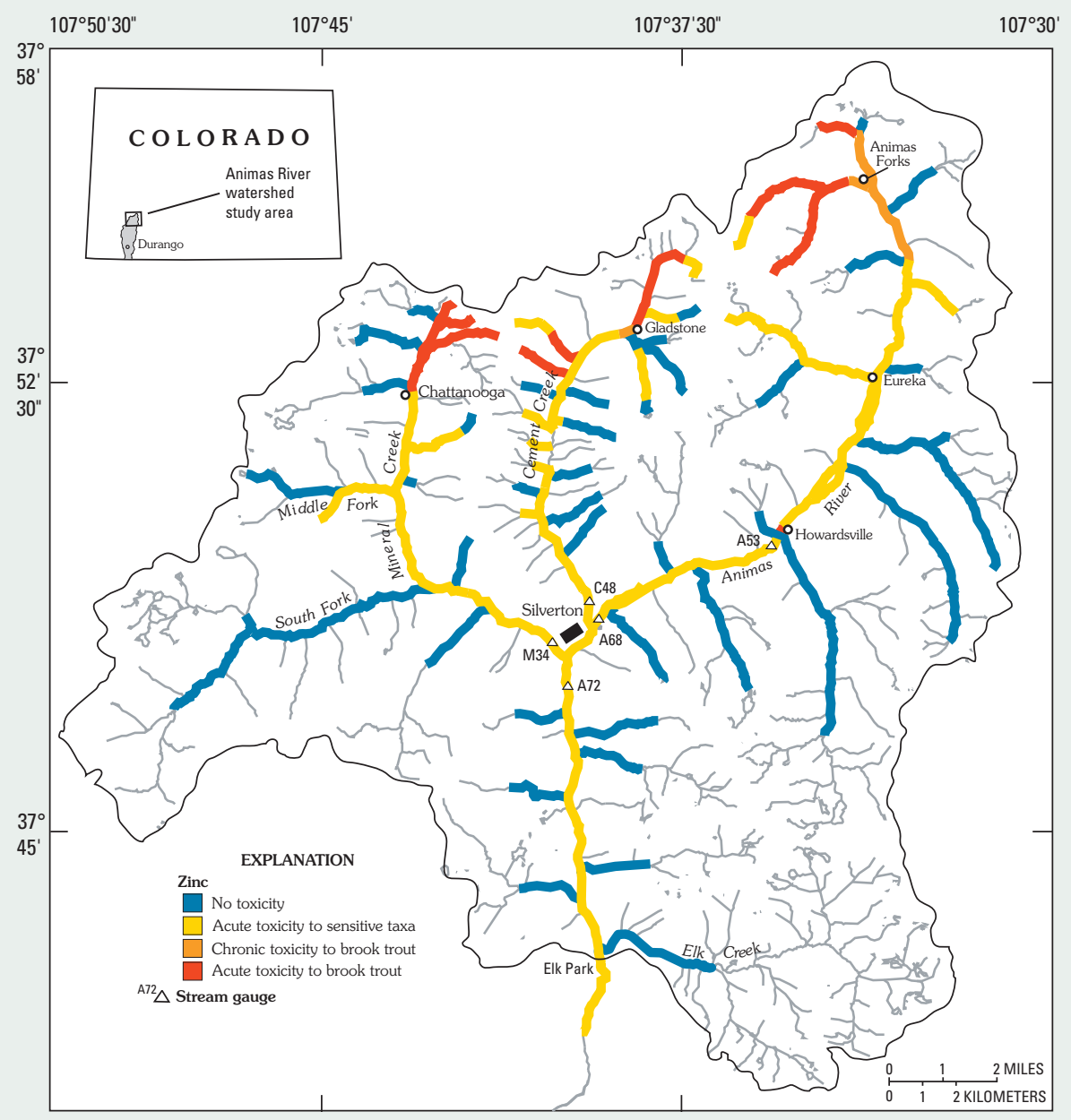

- For further information contact: Stan Church, USGS, Denver, Colo. (303) 236-1900 or schurch@ usgs.gov, or visit the project website: URL: http://amli.usgs.gov/

- For the complete report see: Church, S.E., von Guerard, Paul, and Finger, S.E., eds., 2007, Integrated investigations of environmental effects of historical mining in the Animas River watershed, San Juan County, Colorado: U.S. Geological Survey Professional Paper 1651, 1,096 p. plus CD-ROM. URL: http://pubs.usgs.gov/pp/2007/1651/

- This Fact Sheet is available online at: http://pubs.usgs.gov/fs/2007/3051/

Any use of trade, product, or firm names is for descriptive purposes only and does not imply endorsement by the U.S. Government. 